\title{
Application of the Analytical Hierarchy Process (AHP) to Multi-Criteria Analysis for Contractor Selection
}

\author{
Mohammed Balubaid, Rami Alamoudi \\ Department of Industrial Engineering, King Abdulaziz University, Jeddah, Saudi Arabia \\ Email: mbalubaid@kau.edu.sa
}

Received 4 August 2015; accepted 8 September 2015; published 11 September 2015

Copyright (C) 2015 by authors and Scientific Research Publishing Inc.

This work is licensed under the Creative Commons Attribution International License (CC BY). http://creativecommons.org/licenses/by/4.0/

(c) (7) Open Access

\begin{abstract}
One of the key activities of any client is contractor selection. Without a suitable and precise method for selecting the best contractor, the completion of a project will likely be affected. In this study, we examine the use of the analytical hierarchy process (AHP) as a decision-support model for contractor selection. This model can assist project management teams in identifying contractors who are most likely to deliver satisfactory outcomes in a selection process that is not based simply on the lowest bid. In this study, an AHP-based model is tested using a hypothetical scenario in which candidate contractors are evaluated. Six criteria for the primary objective are evaluated. The criteria used for contractor selection in the model are identified, and the significance of each criterion is determined using a questionnaire. Comparisons are made by ranking the aggregate score of each candidate based on each criterion, and the candidate with the highest score is deemed the best. This study contributes to the construction sector in two ways: first, it extends the understanding of selection criteria to include degrees of importance, and second, it implements a multi-criteria AHP approach, which is a new method for analyzing and selecting the best contractor.
\end{abstract}

\section{Keywords}

Analytical Hierarchy Process, Multi-Criteria Decision-Making, Contractor Selection

\section{Introduction}

According to the Central Department of Statistics and Information of Saudi Arabia, the contribution of the construction industry to the GDP of Saudi Arabia increased from 4.3\% in 2011 to $4.8 \%$ in 2013. The industry's value add increased by 13.4\%, from US\$31.6 billion in 2012 to SAR134.4 billion US\$35.8 billion in 2013.

How to cite this paper: Balubaid, M. and Alamoudi, R. (2015) Application of the Analytical Hierarchy Process (AHP) to Multi-Criteria Analysis for Contractor Selection. American Journal of Industrial and Business Management, 5, 581-589. 
One of the key activities of any client is contractor selection. Without a suitable and precise method for selecting the best contractor, the completion of a project will likely be affected. In this study, we examine the use of the analytical hierarchy process (AHP) as a decision-support model for contractor selection. This model can assist project management teams in identifying contractors who are most likely to deliver satisfactory outcomes in a selection process that is not based simply on the lowest bid.

\section{Literature Review}

\section{Analytic Hierarchy Process}

According to Wang et al. [1], the contractor selection process is a multi-criteria decision-making (MCDM) problem. Numerous MCDM models including utility theory [2] [3], fuzzy theory [4] [5], and performance-based modeling [6] have been developed for contractor qualification or final selection.

The AHP [7] [8] is a decision-making method that was developed by Saaty. This technique calculates the qualified priorities of a given set of alternatives on a scale based on the judgment of the decision-maker. The process stresses the importance of the intuitive judgments of a decision-maker and consistency in the comparison of alternatives in the decision-making process. Skibniewski and Chao [9] suggested that the strength of this approach is that it organizes tangible and intangible factors in a systematic way and offers a structured, simple solution to decision-making problems.

The AHP-based approach has become quite popular primarily due to its simple and systematic implementation steps [7] [10]-[14].

\section{Data Collection and Analysis}

\subsection{Problem Overview}

The evaluation and selection of contractors prior to the award of a construction contract is a vital part of the construction process. Procedures related to the pre-qualification of potential bidders and the assessment of bids submitted by pre-qualified contractors are normally performed by a client's representative and ultimately lead to the selection of a contractor for the project.

The qualification and bid-assessment processes require the development of sufficient and suitable criteria. Project complexity and developer requirements have greatly expanded in the last two decades. This expansion has led to an increased use of alternative forms of project delivery systems. Conversely, the qualification and bid evaluation processes, which involve the quantification and the assessment of criteria, have remained unchanged.

Applying a decision-making tool such as the AHP to contractor selection and qualification can be particularly useful to ensure that a project is successful because selecting a qualified and capable contractor to complete any project increases the likelihood of a timely delivery of results that are within the allocated budget and of acceptable quality.

The model used in this study was developed based on two questions, which included all of the questions for level 1 of the hierarchy shown in Figure 1. Level 2 of the hierarchy was not part of the questionnaire due to confidentiality reasons.

The questionnaire was distributed to subject matter experts in the fields of contract procurement and project management from various departments at Saudi Aramco including the contracting department, the project management team (PMT) and the project management office department (PMOD). Table 1 shows the types of questions used for data collection.

\subsection{Data Collection}

Interviews and meetings were conducted with various groups of individuals involved in the contract procurement process and project management including senior project engineers, project managers, contract advisors, and project controllers. Based on previous information, we developed a questionnaire to collect the required data. The AHP model was formulated after the data were gathered from all of the questionnaire responses.

\subsection{Building the Model}

Given the dimensions and the merits of the problem, the model was developed to select the most appropriate 


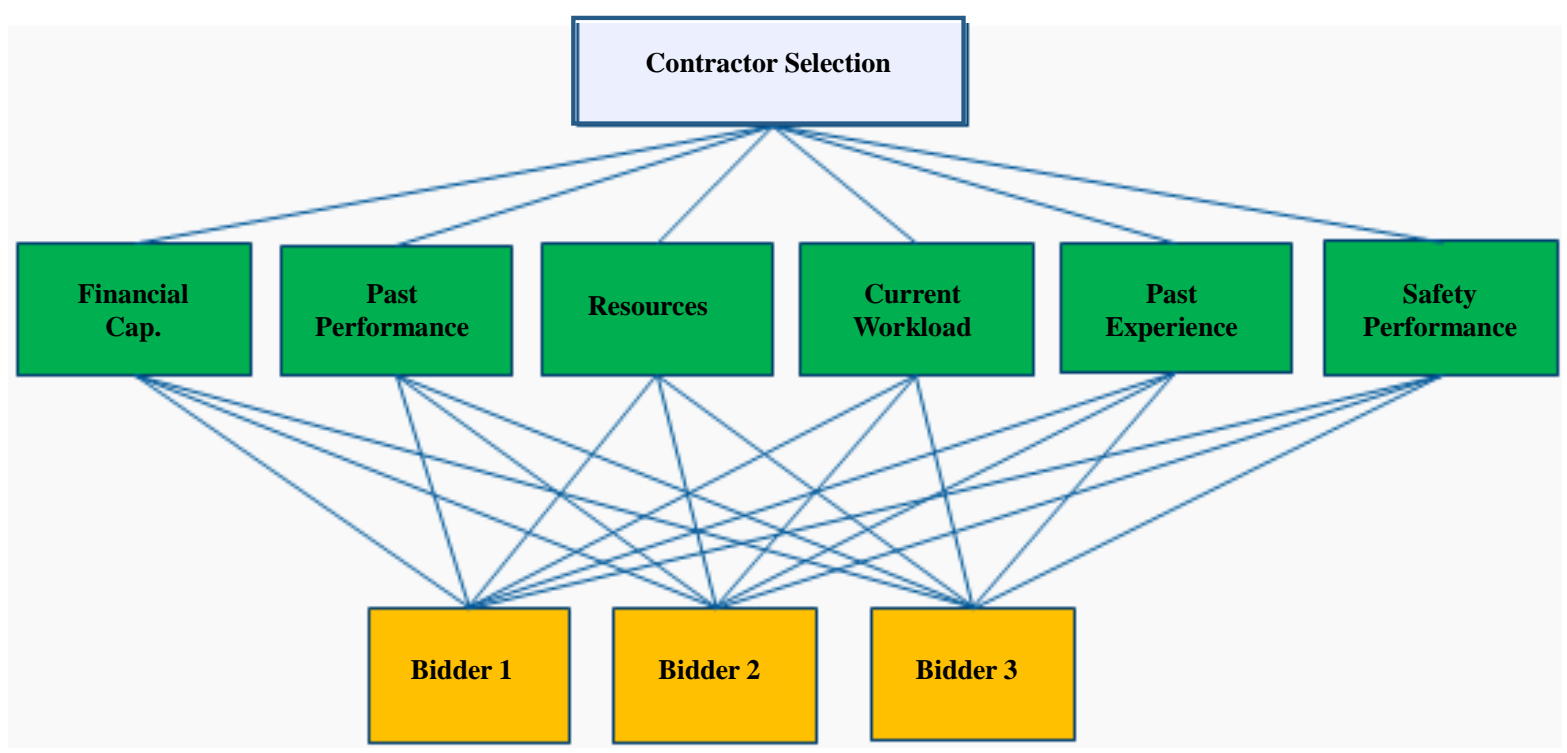

Figure 1. Final structure of the AHP model.

Table 1. Types of questions used for data collection.

\begin{tabular}{cccc}
\hline No. & Question & Category & Possible Answer \\
\hline $\mathbf{1}$ & How much more important do you think "Factor 1" is than "Factor 2"? & For Criteria & Scale from 1 to 9 \\
\hline
\end{tabular}

contractor for the project.

\subsubsection{Decision Making}

The AHP technique was used to select the most qualified and capable contractor to complete the project. The following six criteria for the contractors were chosen from the hierarchy structure:

- Financial Capability

- Past Performance

- Contractor's Past Experience

- Contractor's Resources

- Current Workload

- Safety Performance

All of these criteria were evaluated with respect to the primary objective, which was to select the most qualified and competent contractor for the contract. Ratings were assessed via surveys, which were distributed to subject matter experts in the areas of project management and contract procurement.

\subsubsection{Most Commonly Qualified Contractor (Alternatives-Level 2)}

Because of confidentiality reasons the identities of the contractors have not been disclosed. The purpose of this analysis was to develop an effective decision-making technique and apply it to contractor qualification and final selection using certain criteria.

\subsection{Questionnaire}

Questionnaires were used for data collection to prioritize the criteria and rate the relative importance of each criterion used in the AHP model. The survey was distributed to subject matter experts in the fields of project management, contract procurement and contractor evaluation. Contractors play critical roles in the success of any project, particularly in construction; therefore, selecting the most qualified primary contractor to complete the project is critical to the project's success. A pre-determined set of qualifying criteria are used to eliminate undesirable contractors from the bidding process, thus ensuring that the project is completed within the allocated 
budget, on schedule, safely, and to a desired level of quality. The following criteria were used for contractor qualification.

\section{Financial Capability/Past Performance/Past Experience/Resources/Current Workload/Safety Performance}

The questionnaire shown below in the appendix was developed to identify the most important criteria used for qualifying contractors during a technical bid evaluation process prior to awarding a contract. Respondents were asked to choose the number that indicated which item in each pair of criteria was a more important qualification criterion for contractor selection.

\subsection{Example: Applying the Six Criteria to All of the Alternatives}

Table 2 is an example in which all of the criteria were applied to three potential bidders interested in the project. As mentioned previously, the example was used only to demonstrate the application of certain criteria to various alternatives. As discussed previously, the names of all of the bidders have been withheld, and the information provided on all of the bidders was hypothetical; the information is listed to demonstrate the application of the method to actual cases.

The average Level 1 scores for the six criteria based on a survey is shown in Table 3. The weight of each criterion at the same level was calculated as follows:

Level 1:

- Calculate the total for each column in the comparison matrix;

- Divide each score by the sum of its column to form a new matrix; and

- Calculate the average of each row in the new matrix to obtain the priority vector weights of each criterion. Table 4 shows the new matrix after the weights were calculated.

The "Average" column above shows the average values of the normalization matrix and is called the priority vector. The priority vector is usually determined by averaging the row entries in the normalization matrix.

Table 5 shows the pair wise comparison and normalization matrices for each criterion.

Table 2. The comparison of Level 2 "alternatives” for the criteria.

\begin{tabular}{|c|c|c|c|}
\hline & Bidder 1 & Bidder 2 & Bidder 3 \\
\hline Financial Capability & \$3 MM Assets & \$3.5 MM Assets & \$2.7 MM Assets \\
\hline Past Performance & Below Average & Average & Above Average \\
\hline Past Experience & No Similar Experience & Good Experience & Good Experience \\
\hline Resources & $\begin{array}{l}\text { Manpower of } 700 \\
\text { with Direct Sponsorship }\end{array}$ & $\begin{array}{l}\text { Manpower of } 400 \text { with Direct } \\
\text { Sponsorship/400 to Be Mobilized Later }\end{array}$ & $\begin{array}{l}\text { Manpower of } 550 \text { with Direct } \\
\text { Sponsorship }\end{array}$ \\
\hline Current Workload & $\begin{array}{l}5 \text { Capital Projects at } \\
\text { Various Locations }\end{array}$ & Two Capital Projects & $\begin{array}{l}\text { One Large Project Nearing Completion, } \\
\text { Two Capital Projects Underway }\end{array}$ \\
\hline Safety Performance & Average & Average & Average \\
\hline
\end{tabular}

Table 3. The average Level 1 scores for the six criteria based on a survey.

\begin{tabular}{|c|c|c|c|c|c|c|}
\hline & $\begin{array}{l}\text { Financial } \\
\text { Capability }\end{array}$ & $\begin{array}{c}\text { Past } \\
\text { Performance }\end{array}$ & $\begin{array}{c}\text { Past } \\
\text { Experience }\end{array}$ & Resources & $\begin{array}{c}\text { Current } \\
\text { Workload }\end{array}$ & $\begin{array}{c}\text { Safety } \\
\text { Performance }\end{array}$ \\
\hline Financial Capability & 1 & 1 & 3 & 0.5 & 2 & 3 \\
\hline Past Performance & 1 & 1 & 7 & 1 & 7 & 2 \\
\hline Past Experience & 0.33 & 0.14 & 1 & 0.25 & 3 & 1 \\
\hline Resources & 2 & 1 & 4 & 1 & 7 & 1 \\
\hline Current Workload & 0.5 & 0.14 & 0.33 & 0.14 & 1 & 0.5 \\
\hline Safety Performance & 0.33 & 0.5 & 1 & 1 & 2 & 1 \\
\hline
\end{tabular}


Table 4. The Level 1 normalization matrix of Level 1 for the six criteria.

\begin{tabular}{ccccccccc}
\hline & $\begin{array}{c}\text { Financial } \\
\text { Capability }\end{array}$ & $\begin{array}{c}\text { Past } \\
\text { Performance }\end{array}$ & $\begin{array}{c}\text { Past } \\
\text { Experience }\end{array}$ & Resources & $\begin{array}{c}\text { Current } \\
\text { Workload }\end{array}$ & $\begin{array}{c}\text { Safety } \\
\text { Performance }\end{array}$ & Average \\
\hline Financial Capability & 0.194 & 0.264 & 0.184 & 0.128 & 0.091 & 0.353 & 0.192 \\
Past Performance & 0.194 & 0.264 & 0.43 & 0.257 & 0.318 & 0.235 & 0.279 \\
Past Experience & 0.064 & 0.0377 & 0.061224 & 0.06422 & 0.14 & 0.118 & 0.078 \\
Resources & 0.39 & 0.2642 & 0.245 & 0.256881 & 0.318 & 0.118 & 0.264 \\
Current Workload & 0.1 & 0.038 & 0.02041 & 0.037 & 0.045 & 0.059 & 0.048 \\
Safety Performance & 0.064 & 0.132 & 0.061224 & 0.257 & 0.091 & 0.118 & 0.140 \\
\hline
\end{tabular}

Table 5. The pairwise comparison and normalization matrices for each criterion.

\begin{tabular}{|c|c|c|c|c|c|c|c|c|}
\hline \multicolumn{4}{|c|}{ Pairwise Comparison Matrix } & \multicolumn{5}{|c|}{ Normalization Matrix } \\
\hline Financial Cap. & Bidder 1 & Bidder 2 & Bidder 3 & Financial Cap. & Bidder 1 & Bidder 2 & Bidder 3 & Avg. \\
\hline Bidder 1 & 1 & $1 / 2$ & 7 & Bidder 1 & 0.318 & 0.077 & 0.854 & 0.416 \\
\hline Bidder 2 & 2 & 1 & $1 / 5$ & Bidder 2 & 0.636 & 0.154 & 0.024 & 0.272 \\
\hline Bidder 3 & $1 / 7$ & 5 & 1 & Bidder 3 & 0.045 & 0.769 & 0.122 & 0.312 \\
\hline SUM & 3.143 & 6.5 & 8.2 & & & & & \\
\hline Work-Load & Bidder 1 & Bidder 2 & Bidder 3 & Work-load & Bidder 1 & Bidder 2 & Bidder 3 & Avg. \\
\hline Bidder 1 & 1 & 3 & 2 & Bidder 1 & 0.545 & 0.375 & 0.615 & 0.512 \\
\hline Bidder 2 & $1 / 3$ & 1 & $1 / 4$ & Bidder 2 & 0.182 & 0.125 & 0.077 & 0.128 \\
\hline Bidder 3 & $1 / 2$ & 4 & 1 & Bidder 3 & 0.273 & 0.5 & 0.308 & 0.360 \\
\hline SUM & 1.833 & 8 & 3.25 & & & & & \\
\hline Past Performance & Bidder 1 & Bidder 2 & Bidder 3 & Past Performance & Bidder 1 & Bidder 2 & Bidder 3 & Avg. \\
\hline Bidder 1 & 1 & $1 / 3$ & 4 & Bidder 1 & 0.235 & 0.1 & 0.727 & 0.354 \\
\hline Bidder 2 & 3 & 1 & $1 / 2$ & Bidder 2 & 0.706 & 0.3 & 0.091 & 0.366 \\
\hline Bidder 3 & $1 / 4$ & 2 & 1 & Bidder 3 & 0.059 & 0.6 & 0.182 & 0.280 \\
\hline SUM & 4.25 & 3.33 & 5.5 & & & & & \\
\hline Safety Performance & Bidder 1 & Bidder 2 & Bidder 3 & Safety Performance & Bidder 1 & Bidder 2 & Bidder 3 & Avg. \\
\hline Bidder 1 & 1 & 9 & 6 & Bidder 1 & 0.240 & 0.878 & 0.545 & 0.555 \\
\hline Bidder 2 & 3 & 1 & 4 & Bidder 2 & 0.720 & 0.098 & 0.364 & 0.394 \\
\hline Bidder 3 & $1 / 6$ & $1 / 4$ & 1 & Bidder 3 & 0.04 & 0.024 & 0.091 & 0.052 \\
\hline SUM & 4.167 & 10.25 & 11 & & & & & \\
\hline Past Experience & Bidder 1 & Bidder 2 & Bidder 3 & Past Experience & Bidder 1 & Bidder 2 & Bidder 3 & Avg. \\
\hline Bidder 1 & 1 & $1 / 6$ & 4 & Bidder 1 & 0.138 & 0.04 & 0.75 & 0.309 \\
\hline Bidder 2 & 6 & 1 & $1 / 3$ & Bidder 2 & 0.828 & 0.24 & 0.063 & 0.377 \\
\hline Bidder 3 & $1 / 4$ & 3 & 1 & Bidder 3 & 0.034 & 0.72 & 0.188 & 0.314 \\
\hline SUM & 7.25 & 4.167 & 5.33 & & & & & \\
\hline Resources & Bidder 1 & Bidder 2 & Bidder 3 & Resources & Bidder 1 & Bidder 2 & Bidder 3 & Avg. \\
\hline Bidder 1 & 1 & 7 & $1 / 9$ & Bidder 1 & 0.099 & 0.848 & 0.022 & 0.323 \\
\hline Bidder 2 & $1 / 7$ & 1 & 4 & Bidder 2 & 0.014 & 0.121 & 0.783 & 0.306 \\
\hline Bidder 3 & 9 & $1 / 4$ & 1 & Bidder 3 & 0.887 & 0.03 & 0.196 & 0.371 \\
\hline SUM & 10.143 & 8.25 & 5.111 & & & & & \\
\hline
\end{tabular}




\subsection{Consistency Ratio}

The consistency ratio for each criterion at the same level was calculated as follows:

Level 1:

- Multiply the "Weight" column by the Level-1 matrix in Table 6, and then obtain a new matrix, which is shown in Table 7;

- Find the sum of each row, as shown in Table 8;

- Divide the "Sum" column by the "Weight" column to find the average of that column $\left(\lambda_{\max }\right)$, as shown in Table 9;

- Find the average of the column that was obtained in the previous step;

- Calculate the consistency index using the following formula:

$$
\mathrm{CI}=\left(\lambda_{\max }-n\right) /(n-1)
$$

where $n=6$ represents the number of factors and $\lambda_{\max }$ is the average of the sum column;

- Find the consistency ratio using the following formula:

$$
\mathrm{CR}=\mathrm{CI} / \mathrm{RI}
$$

where $\mathrm{RI}=1.41$.

Averaging these results yields:

$$
\lambda_{\max }=(7.042+6.785+6.8+6.48+6.604+5.57) / 6=6.547
$$

The consistency index, CI, for two terms is as follows:

$$
\mathrm{CI}=\left(\lambda_{\max }-n\right) /(n-1)=(6.547-6) / 5=0.1094
$$

\begin{tabular}{|c|c|c|c|c|c|c|}
\hline & $\begin{array}{l}\text { Financial } \\
\text { Capability }\end{array}$ & $\begin{array}{c}\text { Past } \\
\text { Performance }\end{array}$ & $\begin{array}{c}\text { Past } \\
\text { Experience }\end{array}$ & Resources & $\begin{array}{c}\text { Current } \\
\text { Workload }\end{array}$ & $\begin{array}{c}\text { Safety } \\
\text { Performance }\end{array}$ \\
\hline Financial Capability & 1 & 1 & 3 & 0.5 & 2 & 3 \\
\hline Past Performance & 1 & 1 & 7 & 1 & 7 & 2 \\
\hline Past Experience & 0.33 & 0.14 & 1 & 0.25 & 3 & 1 \\
\hline Resources & 2 & 1 & 4 & 1 & 7 & 1 \\
\hline Current Workload & 0.5 & 0.14 & 0.33 & 0.14 & 1 & 0.5 \\
\hline Safety Performance & 0.33 & 0.5 & 1 & 1 & 2 & 1 \\
\hline Sum & 5.16 & 3.79 & 16.33 & 3.89 & 22 & 8.5 \\
\hline
\end{tabular}

The consistency ratio, $\mathrm{CR}$, is $\mathrm{CI} / \mathrm{RI}$, where $\mathrm{RI}=1.24$ for the six criteria:

\begin{tabular}{|c|c|c|c|c|c|c|c|}
\hline & $\begin{array}{c}\text { Financial } \\
\text { Capability }\end{array}$ & $\begin{array}{c}\text { Past } \\
\text { Performance }\end{array}$ & $\begin{array}{c}\text { Past } \\
\text { Experience }\end{array}$ & Resources & $\begin{array}{c}\text { Current } \\
\text { Workload }\end{array}$ & $\begin{array}{c}\text { Safety } \\
\text { Performance }\end{array}$ & Avg. \\
\hline Financial Capability & 1 & 1 & 3 & 0.5 & 2 & 3 & 0.192 \\
\hline Past Performance & 1 & 1 & 7 & 1 & 7 & 2 & 0.279 \\
\hline Past Experience & 0.33 & 0.14 & 1 & 0.25 & 3 & 1 & 0.078 \\
\hline Resources & 2 & 1 & 4 & 1 & 7 & 1 & 0.264 \\
\hline Current Workload & 0.5 & 0.14 & 0.33 & 0.14 & 1 & 0.5 & 0.048 \\
\hline Safety Performance & 0.33 & 0.5 & 1 & 1 & 2 & 1 & 0.140 \\
\hline
\end{tabular}

Table 6. Shows a pair wise comparison matrix at Level 1 for the six criteria.

Table 7. The actual pair wise and average values of the normalization matrix priority vector. 
Table 8. Consistency ratio calculation.

\begin{tabular}{cccccccc}
\hline & $\begin{array}{c}\text { Financial } \\
\text { Capability }\end{array}$ & $\begin{array}{c}\text { Past } \\
\text { Performance }\end{array}$ & $\begin{array}{c}\text { Past } \\
\text { Experience }\end{array}$ & Resources & $\begin{array}{c}\text { Current } \\
\text { Workload }\end{array}$ & $\begin{array}{c}\text { Safety } \\
\text { Performance }\end{array}$ & Sum \\
\hline Financial Capability & 0.192 & 0.28 & 0.23 & 0.13 & 0.01 & 0.42 & 1.352 \\
Past Performance & 0.192 & 0.28 & 0.55 & 0.26 & 0.33 & 0.28 & 1.893 \\
Past Experience & 0.063 & 0.04 & 0.082 & 0.07 & 0.14 & 0.14 & 0.53 \\
Resources & 0.384 & 0.28 & 0.31 & 0.26 & 0.33 & 0.14 & 1.711 \\
Current Workload & 0.1 & 0.04 & 0.03 & 0.04 & 0.05 & 0.07 & 0.317 \\
Safety Performance & 0.06 & 0.14 & 0.08 & 0.26 & 0.1 & 0.14 & 0.780 \\
\hline
\end{tabular}

Table 9. The numbers divided by their priorities.

\begin{tabular}{cccc}
\hline & Cons & Avg. & Cons/Avg \\
\hline Financial Capability & 1.352 & 0.192 & 7.042 \\
Past Performance & 1.893 & 0.279 & 6.785 \\
Past Experience & 0.530 & 0.078 & 6.8 \\
Resources & 1.711 & 0.264 & 6.48 \\
Current Workload & 0.317 & 0.048 & 6.604 \\
Safety Performance & 0.780 & 0.140 & 5.57 \\
Avg. & & & $\mathbf{6 . 5 4 6}$ \\
\hline
\end{tabular}

$$
\mathrm{CR}=\mathrm{CI} / \mathrm{RI}=0.1094 / 1.24=0.088
$$

The value of the consistency ratio CR is less than 0.10 , which is well within the acceptable range.

\subsection{Overall Priority Vector}

The overall priorities were determined by multiplying the priority vectors of the criteria by the priorities for each alternative decision for each objective.

Based on Table 10 and Table 11, the best contractor was Bidder\#1.

\section{Conclusions}

Multi-criteria selection methods should be implemented in project management to select the "best" contractors to achieve the project objectives. Contractor selection is a critical task for ensuring that a project is completed within budget and on schedule and that the results are of good quality. The goal of multi-criteria contractor selection is to identify the "best" contractor from a set of available options using an assessment based on multiples election objectives. The selection of a suitable contractor is highly beneficial and avoids many risks that might be encountered if a less capable contractor was awarded the project.

The AHP has emerged as a powerful tool that is applicable to all fields of decision-making to choose the best overall alternative based on selected criteria.

Additionally, because of its flexibility and efficiency, the AHP has been chosen as a reliable instrument for decision-making or problem-solving in the field of project management, particularly in contractor selection.

The decision model for contractor selection examined in this study involved multiple criteria that were evaluated simultaneously by aggregating the knowledge of experts and managing uncertain information. A model based on the AHP technique was applied to determine the order of the criteria to identify the relative importance of each criterion. This model was then used to determine the best alternative (i.e., bidder) to ensure a favorable outcome. 
Table 10. Overall priority vectors.

\begin{tabular}{cccccc}
\hline Financial Capacity & Past Performance & Past Experience & Resources & Current Workload & Safety Performance \\
\hline $\mathbf{0 . 1 9 2}$ & 0.279 & 0.078 & 0.264 & 0.048 & 0.140 \\
\hline
\end{tabular}

Table 11. Priority vector for various alternatives.

\begin{tabular}{cccccccc}
\hline & $\begin{array}{c}\text { Financial } \\
\text { Capability }\end{array}$ & $\begin{array}{c}\text { Past } \\
\text { Performance }\end{array}$ & $\begin{array}{c}\text { Past } \\
\text { Experience }\end{array}$ & $\begin{array}{c}\text { Resources } \\
\text { Bidder 1 }\end{array} 0^{\text {Wurkload }} \begin{array}{c}\text { Fofety } \\
\text { Performance }\end{array}$ & $\begin{array}{c}\text { Final Priority } \\
\text { Vector }\end{array}$ \\
\hline Bidder 2 & 0.416 & 0.354 & 0.309 & 0.323 & 0.512 & 0.555 \\
Bidder 3 & 0.312 & 0.366 & 0.377 & 0.306 & 0.128 & 0.394 \\
\hline
\end{tabular}

\section{Acknowledgements}

We would like to thank Eng Mohammed Maki, for data collection and follow up to carry out this work.

\section{References}

[1] Wang, W.C., Yu, W.D., Yang, I.T., Lin, C.C., Lee, M.T. and Cheng, Y.Y. (2013) Applying the AHP to Support the Best-Value Contractor Selection-Lessons Learned from Two Case Studies in Taiwan. Journal of Civil Engineering and Management, 19, 24-36. http://dx.doi.org/10.3846/13923730.2012.734851

[2] Hatush, Z. and Skitmore, M. (1998) Contractor Selection Using Multicriteria Utility Theory: An Additive Model. Building and Environment, 33, 105-115. http://dx.doi.org/10.1016/S0360-1323(97)00016-4

[3] Pongpeng, J. and Liston, J. (2003) TenSeM: A Multicriteria and Multidecision-Makers’ Model in Tender Evaluation. Construction Management and Economics, 21, 21-30. http://dx.doi.org/10.1080/0144619032000065090

[4] Singh, D. and Tiong, R.L.K. (2005) A Fuzzy Decision Framework for Contractor Selection. Journal of Construction Engineering and Management ASCE, 131, 62-70. http://dx.doi.org/10.1061/(ASCE)0733-9364(2005)131:1(62)

[5] Li, Y., Nie, X. and Chen, S. (2007) Fuzzy Approach to Prequalifying Construction Contractors. Journal of Construction Engineering and Management ASCE, 133, 40-49. http://dx.doi.org/10.1061/(ASCE)0733-9364(2007)133:1(40)

[6] Alarcón, L.F. and Mourgues, C. (2002) Performance Modeling for Contractor Selection. Journal of Management in Engineering ASCE, 18, 52-60. http://dx.doi.org/10.1061/(ASCE)0742-597X(2002)18:2(52)

[7] Saaty, T.L. (1978) Exploring the Interface between Hierarchies, Multiple Objectives and the Fuzzy Sets. Fuzzy Sets and Systems, 1, 57-68. http://dx.doi.org/10.1016/0165-0114(78)90032-5

[8] Saaty, T.L. (1980) The Analytic Hierarchy Process: Planning, Priority Setting, Resource Allocation. McGraw-Hill, NY. $287 \mathrm{p}$.

[9] Skibniewski, M.J. and Chao, L. (1992) Evaluation of Advanced Construction Technology with AHP Method. Journal of Construction Engineering and Management, ASCE, 118, 577-593. http://dx.doi.org/10.1061/(ASCE)0733-9364(1992)118:3(577)

[10] Fong, P.S. and Choi, S.K. (2000) Final Contractor Selection Using the Analytical Hierarchy Process. Construction Management and Economics, 18, 547-557. http://dx.doi.org/10.1080/014461900407356

[11] Al-Harbi, K.M.A. (2001) Application of the AHP in Project Management. International Journal of Project Management, 19, 19-27. http://dx.doi.org/10.1016/S0263-7863(99)00038-1

[12] Anagnostopoulos, K.P. and Vavatsikos, A.P. (2006) An AHP Model for Construction Contractor Prequalification, Operational Research. Anais: An International Journal, 6, 333-346.

[13] Padhi, S.S. and Mohapatra, P.K.J. (2009) Contractor Selection in Government Procurement Auctions: A Case Study, European. Journal of Industrial Engineering, 3, 170-186. http://dx.doi.org/10.1504/EJIE.2009.023604

[14] Dobi, K., Gugic, J. and Kancijan, D. (2010) AHP as a Decision Support Tool in the Multicriteria Evaluation of Bids in Public Procurement. The 32nd International Conference on Information Technology Interfaces (ITI 2010), 21-24 June 2010, Catvat/Dubrovnik, 447-452. 


\section{Appendices}

Extremely Preferred Strongly Preferred Equally Preferred Strongly Preferred Extremely Preferred

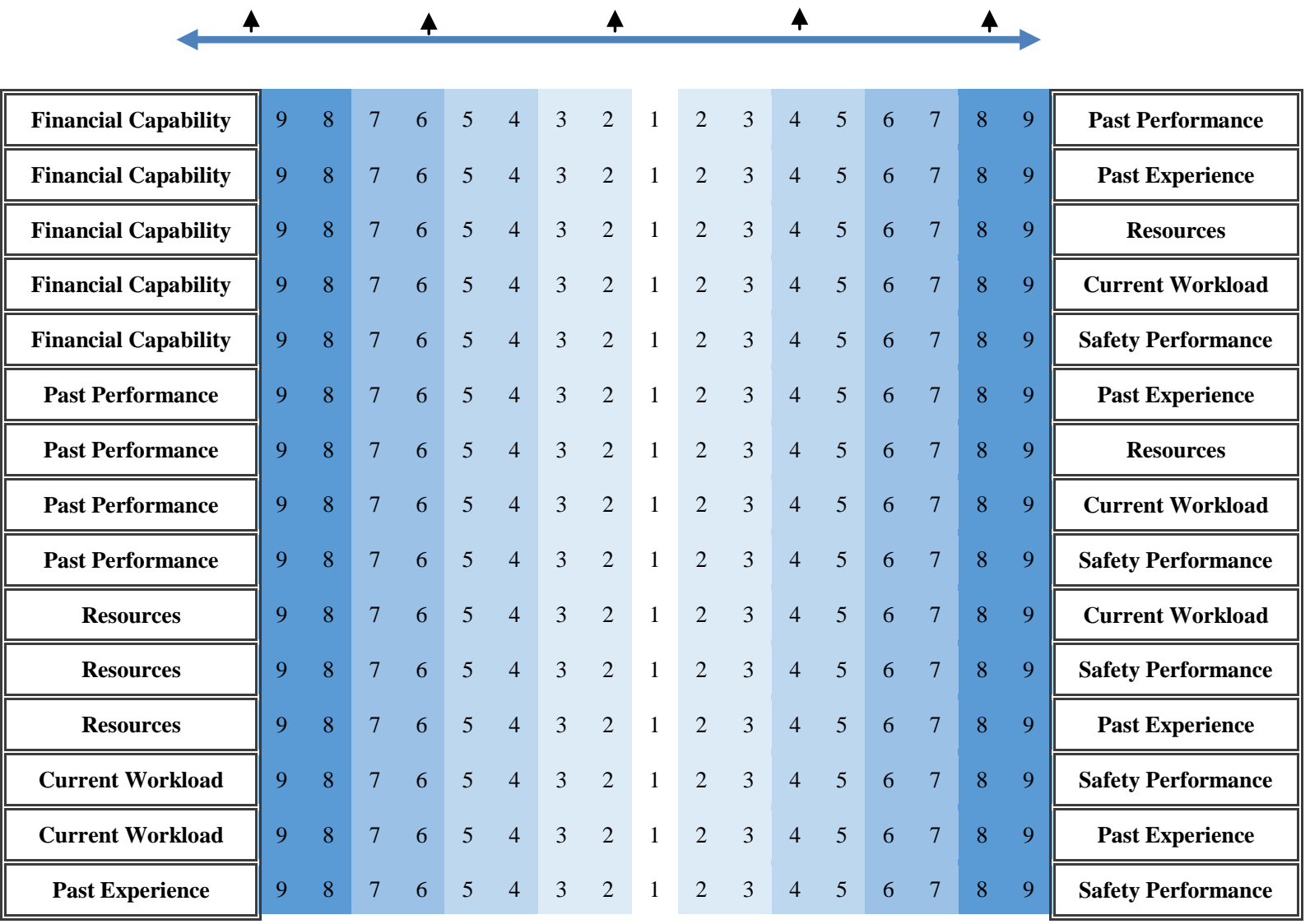

